\title{
Pleasing, Emotionally Touching and Convincing: Erskine Nicol's Painting of Ireland and the Irishin the Mid-Nineteenth Century
}

Plaisant, émouvant et convaincant : la peinture de l'Irlande et des Irlandais par Erskine Nicol au milieu du XIX ${ }^{e}$ siècle

\section{Amélie Dochy}

\section{OpenEdition}

\section{Journals}

Electronic version

URL: https://journals.openedition.org/lbl/1071

ISSN: 2727-9383

Publisher

Université de Bretagne Occidentale - UBO

\section{Printed version}

Date of publication: 1 June 2015

Number of pages: 139-152

ISBN: 979-10-92331-16-5

ISSN: 1270-2412

\section{Electronic reference}

Amélie Dochy, "Pleasing, Emotionally Touching and Convincing: Erskine Nicol's Painting of Ireland and the Irishin the Mid-Nineteenth Century", La Bretagne Linguistique [Online], 19 | 2015, Online since 01 May 2021, connection on 22 May 2021. URL: http://journals.openedition.org/lbl/1071

\section{(c) (7)}

La Bretagne Linguistique est mise à disposition selon les termes de la Licence Creative Commons Attribution 4.0 International. 


\section{Pleasing, Emotionally Touching and Convincing: Erskine Nicol's Painting of Ireland and the Irish in the Mid-Nineteenth Century}

\footnotetext{
E
}

skine Nicol (July 1825-8 March 1904) was a Scottish painter who lived in Dublin between 1845 and 1850. When he went back to Scotland, his paintings attracted the attention of the British public for their fine quality, lively colours and the scenes taken from everyday life. By the 1850s, Nicol was already famous and was celebrated by art critics as the painter of Ireland and Irish themes. He then moved to London in 1862, joined the Royal Academy as an Associate in 1866, and had exhibitions in a variety of places in the capital (notably at the Crystal Palace), in Birmingham, Leeds, Edinburgh, as well as in numerous private galleries. His paintings were so widely reproduced in contemporary art magazines and books that they provided a visual definition of Irish identity, or what he thought to be Irish identity, a significant political issue at the time. In fact, by the 1880 s, Nicol was so influential that any new representation of Ireland was frequently compared to his. Indeed, he managed to touch and convince his public, and simultaneously brought home political messages, particularly when his works were focused on emigration, evictions, or

* Docteur en anglais, Université de Toulouse II. 
the predicaments of Irish peasants. How did he convince the British to share his point of view? This paper will explore Nicol's artistic power to convince through his representations of political issues. First, he was seen as a trustworthy artist, as he regularly travelled in Ireland. Then, he presented convincing subjects, as he mirrored the events depicted in the newspapers. Finally, his paintings had an emotional effect on the viewer, which helped raising the interest of the British public toward Irish issues.

\section{"What all people prefer is preferable to what all do not ${ }^{1 "}$}

Nicol knew the codes which were liable to please his middleclass and upper-middle class audience. Indeed, his paintings are inspired by the popular artistic styles of his day, such as genre painting. Genre painting was appreciated by the Victorians because it depicted scenes from everyday life, in a manner which was inspired by Dutch and Flemish paintings of the sixteenth century. In Scotland, genre painting was made particularly visible on the walls of the Royal Scottish Academy, where Nicol exhibited his first works in the 1840s. At the time, one of the most famous British painters was Nicol's fellow countryman, David Wilkie (1785-1841). The latter had, like Nicol after him, attended the Trustees' Academy, and in his first works, he focused on "the life and manner of the common people ${ }^{2}$ ". After a stay in Ireland in 1835, Wilkie introduced to the British public two large canvasses entitled The Peep-O-Day Boy's Cabin (18351836) and an Irish Whiskey Still (1840), which, according to Fintan Cullen, "conveyed to the metropolis a visual summation of centuries of generalized readings of Ireland: a peasant class who thrived on criminality ${ }^{3}$. In London, this prejudiced approach was yet quite popular, as it offered a sense of drama, so beloved by the Victorians. Nicol was influenced by this type of iconography, as his works are redolent of Wilkie's subjects and style. In his oil on canvas called

1. Aristotle, On Rhetoric, transl. George A. Kennedy, Oxford, Oxford University Press, 2007, p. 70.

2. David \& Francina IRwIN, Scottish Painters, At Home and Abroad, 1700-1900, London, Faber \& Faber, 1975, p. 171.

3. Fintan Cullen, Visual Politics: the Representation of Ireland 1750-1930, Cork, Cork University Press, 1997, p. 116. 
Notice to Quit, one may recognize the brown and green hues used by Wilkie in his works, although his characters are less romanticized.

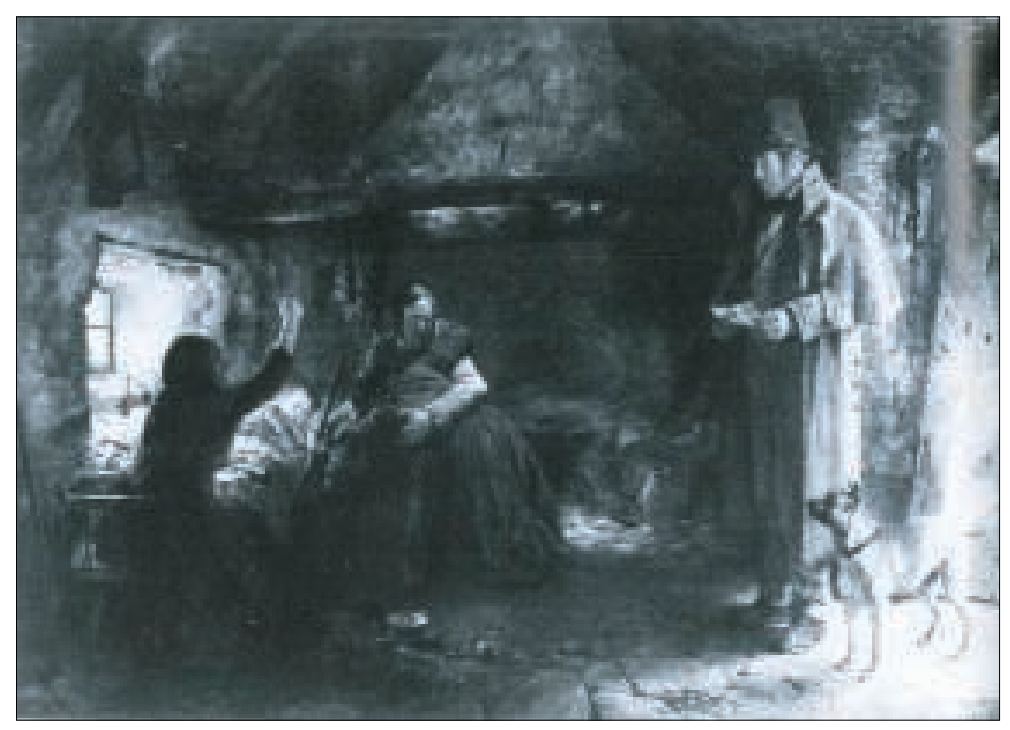

Erskine Nicol, Notice to Quit, oil on canvas, 72 x $105.5 \mathrm{~cm}, 1862$, private collection. @ Amélie Dochy, all rights reserved.

Moreover, when Nicol's canvas was exhibited in the Royal Academy in 1862, it reminded contemporary viewers of another painting by Wilkie named Distraining for Rent, dating back to 1815 . For instance, James Dafforne wrote about the favourable reception won by the painting, as well as its affiliation to Wilkie's work:

“[...] No work [Nicol] had hitherto put before the public in London gained such general favourable criticism as his Notice to Quit which, as regards subject especially, would serve as a companion to Wilkie's Distraining for Rent. It was in the Academy exhibition of 1862, and shows an Irish Cabin of such utter wretchedness that one wonders it would ever be the abode of humanity; and yet its inmates are a married couple, a sick child, and the aged mother of one of the pair. At the door stands the process-server, whose looks certainly do not betoken a disposition to soften the painful nature of his mission by any display of gentleness and suavity: his business is simply to get rid of the tenants, and he is callous to any appeal that might be made to him. The 
wife clings to her husband in despair, and the latter mingles his ban with anathemas of the old woman, who holds up a crucifix to arrest the step of the sheriff's officer. The story is told with great vividness and truth." (James Dafforne, The Art Journal, London, Virtue, 1870, p. 66.)

The work was deemed truthful by contemporary viewers, as they were well prepared to accept this type of representations. Respecting the style and the themes introduced before him by artists such as Wilkie, Nicol succeeded in pleasing his public. Thus, he applied, though probably unconsciously, Aristotle's maxim "What all people prefer is preferable to what all do not". His depiction of this Irish family incorporated elements of genre painting, including the depiction of everyday life, but also of drama, as the viewer may guess the sad fate of these farmers.

\section{A reliable witness}

In addition, as Nicol lived in Ireland at the time of the Great Famine (1846-1851), he was a direct witness to the consequences of potato blight on the Irish population. Contrary to George Frederick Watts, he did not choose to represent famished peasants, but he developed the themes of evictions and emigration in many of his works. It is true that between 1846 and 1854, historians believe that 500000 tenants were evicted by landlords ${ }^{4}$, and more than one million Irish men and women emigrated to Great Britain, and to North America ${ }^{5}$. Thomas Martin Devine notes that those who

4. Laurent Colantonio, «La Grande Famine en Irlande (1846-1851) : objet d'histoire, enjeu de mémoire», Revue Historique, n 644, octobre 2007, p. 899925 , p. 906 . This figure is not only explained by the poverty triggered by potato blight. British legislation is another factor accounting for it, such as the sadly notorious Gregory clause. This clause was passed by the British government in 1847 to amend the Irish Poor Law, and excluded from public relief any peasant who held a land of more than a quarter of acre. Therefore, landlords began to evict the peasants who possessed more than a quarter of an acre, in order not to give them relief themselves. These massive evictions were also linked to the landlords' will to modernize Irish agriculture (see James S. Donnelly, "Mass Eviction and the Irish Famine: The Clearances Revisited", in Cathal Poirteir ed., The Great Irish Famine, Dublin, Mercier Press, 1995, p. 155-173, p. 159-160).

5. Peter Murray writes "Predictably, because it was a traffic shameful to national 
had some means left for America, whereas the poorest emigrated to Great Britain, as the journey was cheaper as well as quicker ${ }^{6}$. As he chose to represent an Irish couple ready to leave their native town, Nicol proved that he was conscious of this reality. In Irish Emigrants Waiting for the Train, a painting exhibited at the Royal Academy in 1864, the artist shows an Irish couple waiting at Ballinasloe station for the Galway train which, according to Síghle Bhreathnach-Lynch, "will take them away from the homeland forever" 7 . The art historian believes that in the painting, "there is nothing [...] to motivate the spectator into questioning the reasons for having to leave ${ }^{8}$. Indeed, as hundreds of Irish migrants came to Great Britain, the British were well aware of the reality of Irish emigration, and as a consequence, the theme developed by Nicol in Irish Emigrants Waiting for the Train depicted an undeniable truth in the eyes of his public. Thus, the artist presented himself as a trustworthy witness, or as someone who could show his good knowledge of his subject, which allowed the public to adhere to his vision of Ireland.

In Irish Emigrants, the melancholic expression of the woman hints at the hardships that the couple had to face before making the decision to leave, which calls for the viewer's compassion. The troubles of these characters are directly linked to their belonging to Ireland, as is suggested by the details painted by Nicol. For example, the Irish identity of the woman is made clear by the artist, who resorts to several physical characteristics which, in his view, alluded to her Irishness: the wife is fair-skinned, dark-haired, and she wears a yellow headscarf, like many other Irish women painted by Nicol. Such pictures offered useful insights into Irish emigration to his

pride, there are few paintings depicting emigrants departing from Ireland's ports" (Peter Murray, "Realism versus Romanticism in Framing National Identity", Whipping the Herring, Survival and Celebration in Nineteenth-Century Irish art, Cork, Crawford Art Gallery and Gandon Editions, 2006, p. 11-23, p. 17).

6. Thomas Martin Devine, "The Great Irish Famine and Scottish History", in Martin J. Mitchell ed., New Perspectives on the Irish in Scotland, Edinburgh, Birlinn, 2008, p. 21-30, p. 22.

7. Síghle Bhreathnach-Lynch, Ireland's Art, Omaha, Creighton University Press, 2007, p. 62.

8. Ibid. 
contemporary public, but also to art lovers of the next generations. Cyril Barrett, in his study of Irish nationalism and art, concludes:

"The best studies of the famine, eviction, destitution and emigration were made by a Scotsman, Erskine Nicol, who studied and worked in Ireland from 1845 till 1850 [...]. But Nicol's work could hardly be called nationalistic: it was sympathetic reporting." (Cyril Barrett, "Irish Nationalism and Art, 1800-1921", Studies: An Irish Quaterly Review, vol. 64, n²56 (Winter, 1975), p. 393-409, p. 401).

Erskine Nicol, Irish Emigrants Waiting for the Train, oil on canvas, $71 \times 53 \mathrm{~cm}, 1864$, Sheffield Museums. (๑) Amélie Dochy, all rights reserved.

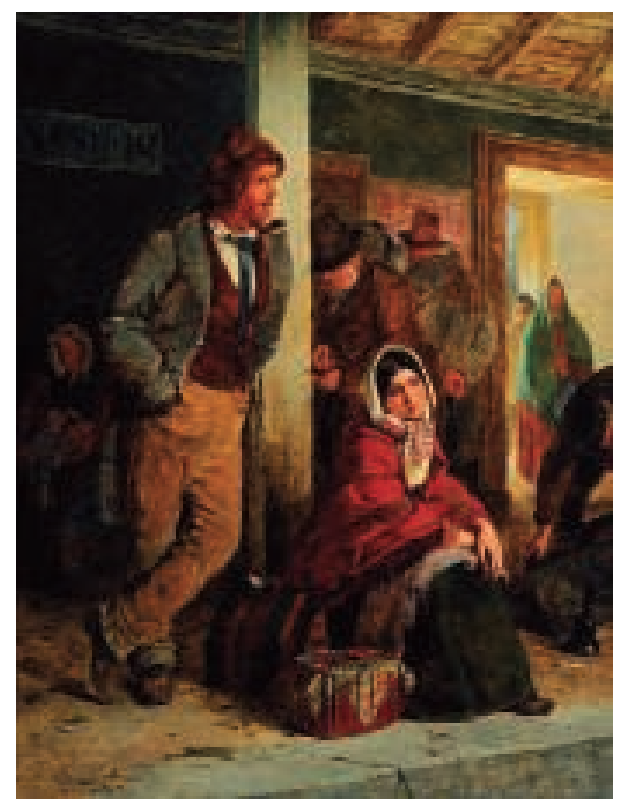

Nicol convinced his public that his representations were faithful to the scenes that he witnessed, and that he was, consequently, a reliable reporter. Furthermore, the scenes represented in his paintings were all the more convincing as they depicted what Nicol's audience could read in newspapers.

In the nineteenth century, the Irish question was at the forefront of British politics, and the troubles in Ireland were carefully reported by newspapers and magazines. Interestingly, the press became more 
and more influential in this century, especially as it was widely circulated. So at the end of the Great Famine, newspapers influenced public opinion when they laid the blame on absentee landlords for the misery and predicaments of Irish peasants, as most of them failed to support their tenants. Thus, those who possessed land in Ireland but lived in Great Britain, leaving the responsibility of their properties to agents, became the target of the British press in the 1860s. They were accused for ignoring the distress of the people who worked on their lands, and for not performing their moral duty. It is in this context that Nicol's work, Renewal of the Lease Refused, was exhibited at the Royal Academy in 1863.

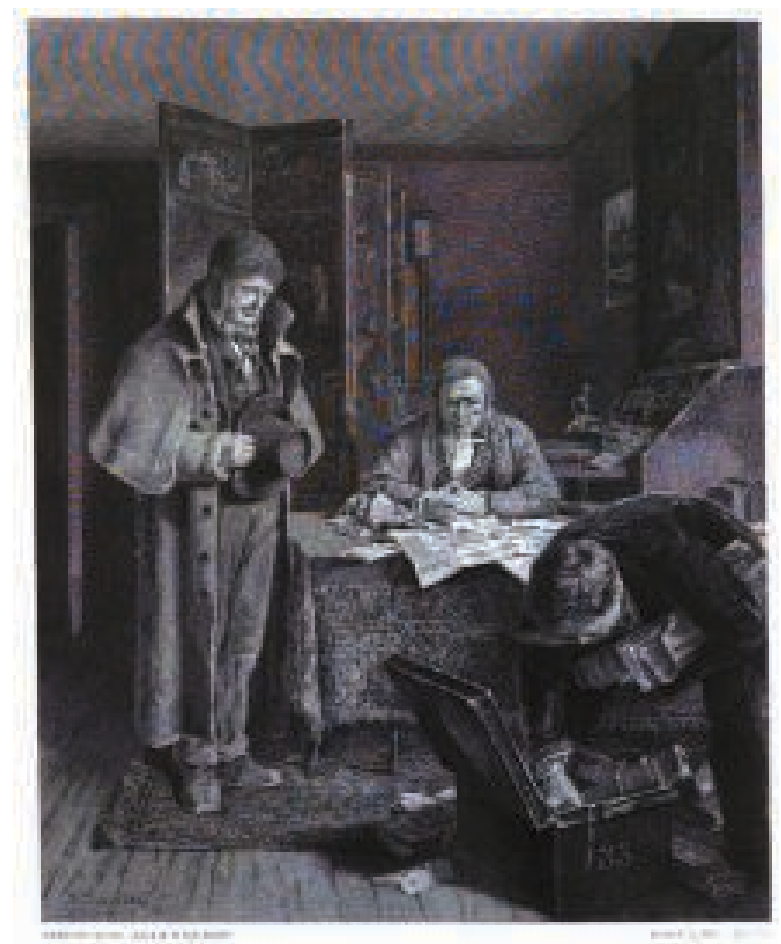

The Renewal of the Lease Refused, black and white engraving by Robert Charles Bell after Nicol's canvas, c. $25.5 \times 33 \mathrm{~cm}$, published on the $1^{\text {st }}$ of March 1870 in The Art Journal, London. @ Amélie Dochy, all rights reserved. 
The work was celebrated by art critics, and was reproduced in magazines in the form of engravings, which made it more popular. The impression shows a dignified Irish peasant, who has come in the office of an estate agent in order to renew his lease, but as the latter refuses, he stands in an embarrassed manner. The viewer may imagine that, deprived of any resources to live on, the peasant and his family are condemned to a life of misery. In this scene, the agent is grimacing, as if to mean that he cannot do anything else, and that it is not in his power to change the decision. This makes the absence of the landlord even more conspicuous: not only is he absent from the scene, but communication with him is impossible for the farmer. Thus, he does not have the chance to explain the consequences of such a decision to the person who made it. So, what Nicol demonstrated in this work was based on the common beliefs of the time, which reinforces the artist's argument. Interestingly, in 1864, a reviewer remarked the violence underlying in such a situation:

"Of course, one guesses how it will end. The poor fellow will be turned out; and some fine night when the agent is riding home from the market town with a comfortable quantity of potheen in him a shot will sputter from behind the hedge, and an Irish nobleman, mostly resident in London, will have to look out for another agent to manage his affairs, and in the market town some six months hence there will be a poor devil to hang who will not be persuaded-let the priest talk over so much - that he is a great sinner on account of the deed which dooms him." ("The Royal Scottish Academy's Exhibition, Third Notice", The Caledonian Mercury, Edinburgh, 18 February 1864, Issue 23282.)

This interpretation can be surprising today, especially as Nicol's protagonist does not express any sign of violence. But one has to bear in mind that contemporary viewers regularly read tales of murdered agents and police officers in the press, especially with the rise of Fenianism (in 1867), an armed organization struggling to set up a republic in Ireland, and then of the Land League, led by Parnell from 1878. Even if the second organization did not entice to physical violence, both movements were associated with violent behaviours, especially in satirical magazines such as Punch or $J u d y^{9}$.

9. Punch and $J u d y$ were both comic weeklies which were established in the middle 
It is true that whenever one has to prove a point, it is easier to select an example, to analyse it, and to declare that, if your conclusion is true for this particular situation, it is most probably true for similar situations. This rhetorical tendency to generalize is another aspect of Nicol's work, which associated violence with the peasant class. This had already been done by David Wilkie, as we have seen, and this is another common point between both painters. In numerous paintings by Nicol, Irish peasants are often represented as violent or boorish characters. This is the case of the oil on board Paying the Rent, dated 1852.

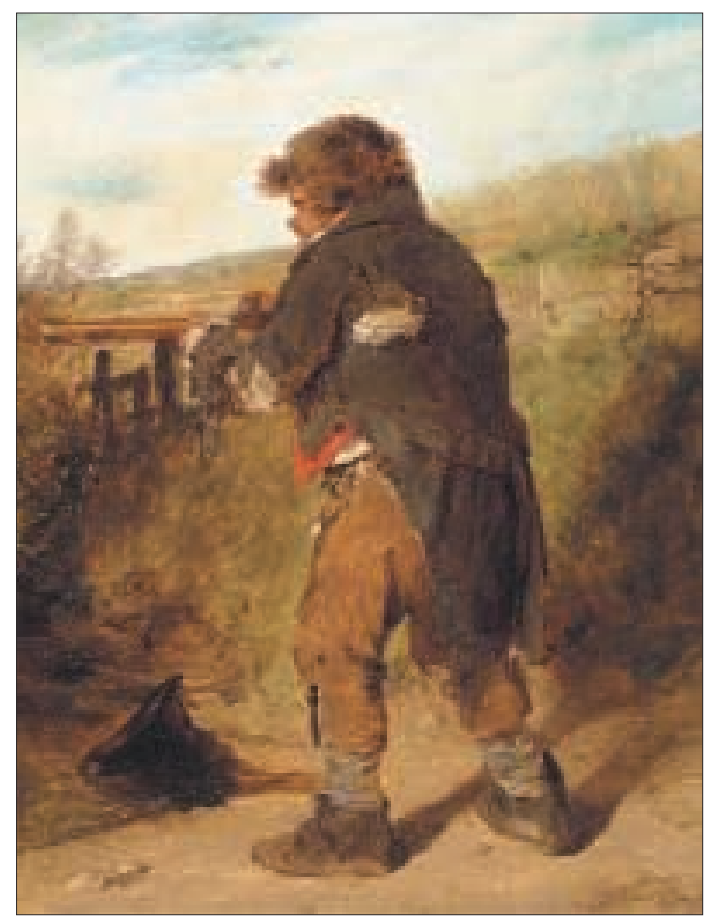

Erskine Nicol, Paying the Rent, oil on board, $32 \times 25 \mathrm{~cm}, 1852$, private collection. Image courtesy of James Adam's.

of the nineteenth century. Created in 1841, Punch was characterized by its caricatures which offered an entertaining vision of contemporary issues, just like $J u d y$, which was published between 1867 and 1907. However, both publications differed in their political perspectives, and Punch frequently adopted a point of view which was less conservative than the one found in Judy. See Michael DE NIE, The Eternal Paddy, Irish Identity and the British Press, 1798-1882, Madison, The University of Wisconsin Press, 2004, p. 27-35. 
In this work, the viewer discovers a sturdy Irishman, dressed in a shabby greenish jacket, whose face shows the smile of a crazed gunman. This type of representation was linked to the policy of the Land League, which encouraged peasants to resist evictions when they did not have the money to pay for the rent. This theme was illustrated by other Nicol's works. A year before Paying the Rent, he had exhibited at the Royal Scottish Academy a painting called $A$ Word or Two on the Rent, a signifying title, and twenty years later, he came back to the subject with a drawing entitled His Rent Day. By repeating similar scenes of this kind, Nicol associated the paying of the rent with violence, an association that his public accepted as a general truth. However, the contemporary viewer will note that these pictures are closer to caricature than to reality.

\section{Playing with humour and pathos}

In the nineteenth century, caricatures of Irishmen were sources of humour for the British public. Of course, these derogatory images were not as well appreciated in Ireland as in Great Britain, but as Nicol mainly sold his caricatures in England and in Scotland, the artist could play with this humorous genre. Thus, he created what Fintan Cullen has called his type of "rustic buffoon ${ }^{10}$ ". Laziness, backwardness, lack of refinement and manner were the main characteristics of the men that he presented in his humorous pieces. This goes back to Aristotle's definition of humour-these are the only words that we have referring to his lost treaty on comedy, which used to be parts of his Poetics, but which has mysteriously disappeared-“some [forms of humour] are appropriate for a gentleman to use and some are not. Each speaker will take up what suits him. Mockery is more gentlemanly than buffoonery; for the mocker makes a joke for his own amusement, the buffoon for the amusement of others ${ }^{11}$ ". In other words, Nicol's form of humour belonged to the second category, as he wanted to entertain his audience. Unsurprisingly, he resorted to buffoons to do so. Playing on the widespread British cliché that the Irish lacked education, he painted The Pursuit of Knowledge under

10. Fintan Cullen, “Nicol, Erskine”, in Jane Turner ed., Dictionary of Art, London, Macmillan, 1996, 34 vols., vol. 23, p. 106-107.

11. Aristotle, op. cit., p. 248. 
Difficulty. This watercolour was probably made by the end of the 1870 s or in the $1880 \mathrm{~s}$, as the name of Parnell is written on one poster, which could be an election poster then. In front of it stands an Irishman, turning his back to the viewer. He is on a quayside, in front of a wall where posters are stuck, and he seems to be reading one of them, which gives details regarding the steam line to New York. The "difficulty" foreshadowed in the title is obvious: this poster is upside down, and the man plunges his hands into the back pockets of his trousers.

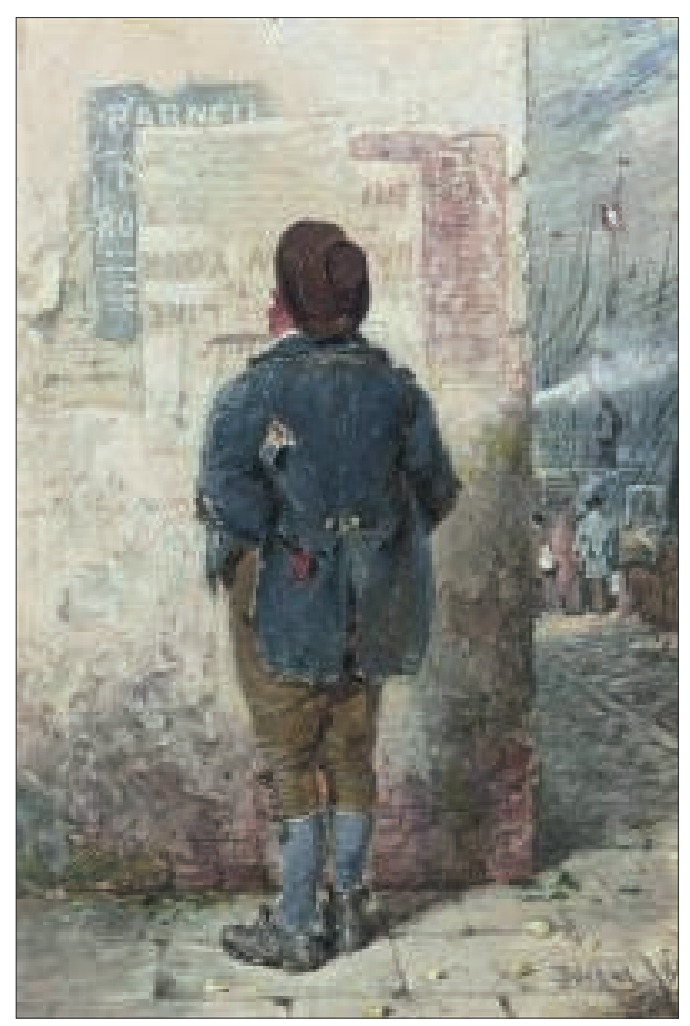

Erskine Nicol, The Pursuit of Knowledge under Difficulty, watercolour, $18 \times 11.5 \mathrm{~cm}$, private collection. @ Amélie Dochy, all rights reserved.

Although his face is partially hidden by his brown hat, we may also clearly distinguish his grimace, with his lower lip protruding. His posture expresses perplexity, and the humour resulting from this effort is at the expense of the protagonist. The title is even more 
significant if the viewer knows that The Pursuit of Knowledge under Difficulty used to be the title of a book designed to help the autodidact to learn reading and writing ${ }^{12}$. In his paintings of Irishmen, Nicol often resorted to mockery, a form of humour which was particularly easy as the nineteenth century was marked by the development of racial theories. In these so-called scientific essays, the authors claimed that the Irish belonged to a different human race (the Celts), much inferior to the British (the Anglo-Saxons), and some contemporaries went as far as speaking of "white chimpanzees", like Charles Kingsley, -an English priest and writer (in a letter to his wife ${ }^{13}$ ). So Nicol's clients appreciated this touch of humour ${ }^{14}$, which accounts for the painter's success: he convinced his public to buy his works by making them laugh and cry.

Indeed, Nicol played with the emotions of his public, another rhetorical technique which helped to convince art collectors to buy works. Aristotle states: "The emotions are those things through which, by undergoing change, people come to differ in their judgements and which are accompanied by pain and pleasure, for example, anger, pity, fear, and other such things and their opposites ${ }^{15}$ ". The pity of the viewer is particularly aroused in Nicol's oil on canvas of 1853 , An Ejected Family. It represents a whole family, made of seven characters, who have just been evicted from their cottage. Their gloomy future is predicted by the bad weather, and by the woman crying on the right-hand side. Moreover, the vision of their farm in the background, in the only sunny part of the painting, stands in sharp contrast with their current predicament. This contrast allows

12. David Newsome, The Victorian World Picture, New Brunswick, Rutgers University Press, 1997, p. 147.

13. Quoted by L. Perry CurTis, Anglo-Saxons and Celts, A Study of Anti-Irish Prejudice in Victorian England, Bridgeport, Connecticut, 1968, p. 84.

14. "The wit, and humour, and peculiar character of the Irishman have proved an unfailing source of amusement [...] in England: the pictures drawn of [Erskine Nicol] by his own countrymen [...] have beguiled many a weary hour on the bed of sickness and suffering, and, for a time at least, have dispelled the gloom which overshadowed the heart". James DAFFORNE, "Erskine Nicol, RSA, ARA", The Art Journal, London, Virtue \& Co., 1870, vol. 9, p. 65. Interestingly, Nicol's representations of Ireland were so predominant in his work that some contemporaries, neglecting his Scottish origins, thought that he was Irish.

15. Aristotle, op. cit., p. 113. 
the viewer to understand the importance of their loss: they have lost their place to live, but also their means of subsistence. Our sympathy is roused by the impending troubles awaiting all the members of this family, including unemployment and hunger. In addition, all ages are represented on the canvas; there are a baby, a child, two women including the mother, two men with the father in the prime of his life, and a miserable grandfather. This favours identification as people "pity those like themselves in age, in character, in habits [...], for in all these cases something seems to apply more to the self ${ }^{16 "}$. This is why the canvas is all the more poignant and touching. With this work, Nicol showed that he was not only a painter of humorous scenes, but also a painter of contemporary tragedies.

\section{Conclusion}

By the 1870s, Erskine Nicol had become very famous thanks to the exhibitions of his works in the British Isles. His paintings were appreciated in Great Britain, and his landscapes and positive depictions of Irish life were equally well accepted in Ireland. He was called "a most skilful delineator of Irishmen and Irish manners ${ }^{17}$ ", or the "well-known delineator of Irish character ${ }^{18 ",}$, whose works were "notable contributions 19 " to the exhibitions at the Royal Scottish Academy, since "Wilkie's mantle" had "gracefully fallen upon" his "shoulder ${ }^{20}$ ". Such a success relied on Nicol's ability to adapt to contemporary taste, and to introduce his production as a trustworthy representation of Irish life. Even though he might have been unaware of it, the characteristics of his works correspond to the rules of rhetoric. He resorted to ethos, or character construction, when he introduced himself as a serious witness of Irish issues, so that his paintings were regarded as reliable documents. This is how the validity of his representations, or logos, was confirmed. The artist painted subjects which mirrored the stories that his contemporaries could read in newspapers, and thus, he gave particular examples

16. ARISTOTLE, op. cit., p. 141.

17. James DAFForne, The Art Journal, March 1870, London, Virtue, p. 200.

18. The Evening Gazette, 11 October 1870, p. 3.

19. Glasgow Herald, 14 February 1870, issue 9397.

20. Caledonian Mercury, 4 September 1855, issue 20572. 
of a general situation regarded as truthful, as in Renewal of the Lease Refused. Finally, he was particularly talented at representing emotions, and this explains the humour or sadness conveyed by his characters. This efficient use of human emotions, affecting the audience in some way, is defined as pathos in rhetoric. Therefore, Nicol's clever combination of ethos, logos and pathos in his compositions convinced the British public of the value of his art. His paintings were bought for extremely high prices by art lovers who hung them in their private collections. This is still true today, as the National Gallery of Ireland has recently paid 130000 euros for one of his best oils entitled The 16th, 17th (St Patrick's Day), and 18th March, showing another of Nicol's artistic interest in his representations of fairs. 